\title{
"Investigating causes of delays and cost escalation in project execution during
}

turnarounds"

$\begin{array}{ll} & \text { Mfanimpela Zacharia Mhlanga } \\ \text { EUTHORS } & \text { Nehemiah Mavetera } \\ & \text { Mfanimpela Zacharia Mhlanga, Elias Munapo and Nehemiah Mavetera (2016). } \\ \text { Investigating causes of delays and cost escalation in project execution during } \\ \text { turnarounds. Investment Management and Financial Innovations, 13(2-2), 334- } \\ \text { 348. doi:10.21511/imfi.13(2-2).2016.08 }\end{array}$

DOI

http://dx.doi.org/10.21511/imfi.13(2-2).2016.08

RELEASED ON

Thursday, 14 July 2016

JOURNAL

"Investment Management and Financial Innovations"

FOUNDER

LLC "Consulting Publishing Company "Business Perspectives"

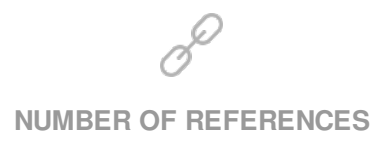

0

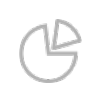

NUMBER OF FIGURES

0

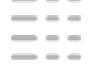

NUMBER OF TABLES

0

(C) The author(s) 2023. This publication is an open access article. 


\title{
Mfanimpela Zacharia Mhlanga (South Africa), Elias Munapo (South Africa), Nehemiah Mavetera (South Africa) \\ Investigating causes of delays and cost escalation in project execution during turnarounds
}

\begin{abstract}
Engen Refinery plant is part of the Engen Petroleum Limited, with operations in Southern Africa. The plant is situated in KwaZulu-Natal province of South Africa and it operates 24 hours a day, every day, including weekends. Although Engen operates 24 hours 7 days a week, the plant has to be shut down occasionally for maintenance. These shutdown periods are also used as an opportunity to implement most projects, especially those that could not be implemented during the normal run of the plant. In order to ensure that the plant operations are not interrupted, it is preferable to work on the equipment while the plant is not operational. The shutdown periods are very limited in time, so it is of utmost importance to complete tasks within the given turnaround period in order to get the plant back on line in time to deliver products as scheduled to customers. The main objective of this study is to explore the causes and consequences of delays in project execution and their impact on the success of the project. The study identified poor communication, repetition of tasks, resource allocation, scope change, procurement process management, inadequate planning and poor budget estimates as major contributors to delays and cost escalation during project execution. It is recommended that Engen Refinery put some means together to improve the above-mentioned issues.
\end{abstract}

Keywords: project, shut down, maintenance, turnaround. JEL Classification: H43.

\section{Introduction}

Engen Refinery plant is part of the Engen Petroleum Limited, with operations in Southern Africa. The refinery is situated in Kwazulu-Natal Province, in Wentworth south of Durban, South Africa, where the crude oil is refined into different products including, but not limited to, petrol, jet fuel, LP Gas, diesel, oil, and other solvents and wax products. Although Engen operates 24 hours 7 days a week, the plant has to be shut down occasionally for maintenance. These periods may range from two to eight weeks, and it is done during time when equipment is fixed/replaced and routine checks are done. These shutdown periods are also used as an opportunity to implement most projects, especially those that could not be implemented during the normal run of the plant. In order to ensure that plant operations are not interrupted, it is preferable to work on the equipment while the plant is not operational. The shutdown periods are very limited in time. It is of utmost importance to complete tasks within the given turnaround period in order to get the plant back on line in time to deliver products as scheduled to customers. If for some reasons these target periods for the shutdown are not met due to delays in one or other project, the impact to the business becomes huge.

(C) Mfanimpela Zacharia Mhlanga, Elias Munapo and Nehemiah Mavetera, 2016

Mfanimpela Zacharia Mhlanga, Graduate School of Business and Leadership, University of KwaZulu-Natal, South Africa.

Elias Munapo, School of Economics and Decision Sciences, North West University, South Africa.

Nehemiah Mavetera, School of Economics and Decision Sciences, North West University, South Africa.
Motivation of the study. This study aims to identify the main causes of delays in project execution and cost escalations during turnarounds. The outcome thereof will be used to implement preventative actions that will stop repetition in delays and cost escalations. The impact in terms of cost and reputation due to customer dissatisfaction when Engen cannot supply customers with products on time is huge and it cannot be tolerated. Understanding the main causes of the delays and the cost escalations will add value to the organization, when preventative actions are put in place to avoid repetitions. Things will be done differently to complete tasks within schedule and saving costs, and most importantly to satisfy customers and maintain a good reputation. The effects of delays at Engen Refinery include, but are not limited to the following:

- The turnaround is not completed on time.

- The work extends hours to catch up, resulting in stress and fatigue.

- The organization has to import products that the refinery could not produce.

- The quality of work is compromized, resulting in much repetition of work.

- The budget is exceeded by huge amounts.

- Customer dissatisfaction.

- Image and reputation damage.

Focus of the study. The study will focus on delays in project execution during turnarounds and cost escalation in those projects executed within the turnaround periods, specifically at the Engen Refinery plant. The project management processes and its elements, applied while correct assistance in 
the smooth execution of any project and in the prevention and reduction of delays, will be scrutinized. The cost of a project is coupled to the schedule, as the schedule slips the cost escalates. The study will also target the personnel who are involved in the turnarounds, including the project planning department, project engineering section, supervision personnel, installation and construction personnel and the maintenance team.

\section{Literature review}

Poor communications, insufficient resources allocation, inadequate risk management and poor quality control during execution could directly result in cost escalations. Projects must be completed in record time to take advantage of the market and other opportunities (Budd \& Budd, 2003). The project management process is reviewed to gain insight into the requirements of project management execution. Projects vary in size, scope, cost and time, ranging from small to big projects. The distinctive features of a project include, but are not limited to, start and finish, project life cycle, a budget with forecast cash flow, the activities, the use of the resources, a single point of responsibility, fast tracking and team roles (Burke, 2013 and Doloi, 2013). According to Hjelmbrekke and Lohne (2014), there is a need for a project governance body.

1.1. Project execution management. Many activities and projects overlap within the manufacturing industries, especially during shutdown periods. Projects are executed to satisfy the project specifications. During the execution phase, it is required that a project will be closely coordinated between the operations team, the manufacturing plant team, functional management, installation contractors, the commissioning team, sponsors and the start-up team (Hagen \& Park, 2013). In PMBOK (2013), a project is defined as a planned temporal endeavor undertaken to create a unique product or offer a service within a limited time scale and allocated budget.

The main objective of a project in manufacturing organizations is to accomplish all tasks safely, on time, within budget and without compromizing any quality. Sondalini (2009) stipulates that customer requirements will include safety, reliability in operations, schedule, budget, flawless start-up and no repetition of work. Most projects in manufacturing industries require the plant to be shut down, as work cannot be done safely while the plant is online. The shutdown steps consist of planning, pre-shut activities, shutdown and post-shut compliance (Sondalini, 2009; Cameron, 2014).

If shutdown steps are not followed, the industry's reputation is compromized, trust is destroyed and the investors have to pay more. According to Sharad (2015), engineering and construction projects put more effort and time into the technical aspects, safety and regulations requirements. This causes time lapse and cost escalation, and by the time implementation is required or due the socioeconomic and industrial environment has changed.

1.2. Project management activities. Almost every industry is concerned about effective management of large-scale complicated projects. Most of the money in cost overruns is wasted due to poor planning while unnecessary delays happen as a consequence of poor scheduling (Render et al., 2015). The first step in planning and scheduling should be to develop the work breakdown structure (WBS). A strategic management theory would offer insights that could be leveraged to make organizational project management environments more effective through improved research foundations (Drouin \& Jugdev, 2014). It is important that project managers learn from their past experiences (Savelsburgh et al., 2016).

1.3. Project management process. Projects are the vehicles by which business opportunities are turned into valued business assets. Successful projects are defined as the ones that are delivered on time, within budget, and meet established business objectives. If a company chooses and builds good projects, it could increase its revenues, decrease life cycle costs, and use less capital to achieve its business goals (Lavingia, 2003). The project management process relies primarily on project plans, as the project plans represent the scope of work that will be achieved through the plan (Rolstadas et al., 2014).

1.4. Scope management. The scope is the most important element of project management, as it determines the activities of the project, and the duration, cost and resources required. Scope creep can happen in any project, resulting in time wastage, money wastage, and diminished satisfaction due to the fact that project value is not realized (Larson \& Larson, 2009). Scope change during execution might be inevitable as stipulated by Erlt (2014). These changes happen when some equipment is opened, cleaned or inspected. This scope change should be managed and controlled very closely, as it may result in huge cost and massive delays.

1.5. Time management. It is the wish of everyone to complete a project timeously (Assaf and Al-Hejji, 2003). Delays are not acceptable, because they result in huge costs, including production costs. Every activity has a time frame attached to it, and a delay in those activities may accumulate into huge delays if not monitored closely (Ertl, 2014). 
A successful project is defined as the one that achieves the objectives of the full scope, within schedule and authorized budget. In most cases, the budget is compromized to deliver on time (Albrecht and Spang, 2014). The sooner the organization completes the project, the sooner it may reap the benefits (Patrick \& Warchalowski, 2013).

1.6. Cost management. Cost management is one of the most primary functions of project managers. One of the core functions of project management is cost integrated with scope, quality and time management. Success of a project is measured through management of cost during the life cycle of the project. Effective capital budgeting include the identification of the environmental costs and benefits, which include the direct and indirect future liabilities, managerial costs, insurance and risks management. Research to minimize costs in projects is ongoing. Lahdenperä (2016) produced a requirement framework for a two-stage target cost (2STC) model to allow functioning models to be formulated and tested. The framework incorporated numerous requirements, constraints and a suggested path forward. The study by Andersen et al. (2016) concluded that underestimation in the front-end phase was significant in the sample used and poses a serious problem that suboptimal projects are approved. The causes of underestimation include underestimating risk, overestimating opportunities, inadequate estimation methods and skills, reliance on weak information, and strategic/deliberate scope creep and division of projects. Conclusive evidence from Dursun and Stoy (2016) suggests that the multistep ahead (MSA) approach significantly outperforms the prediction accuracy of the conventional practice in projects.

1.7. Quality management. According to Ertl (2014), the quality planning, quality assurance and quality control are included in this phase. This ensures that the project meets the intended objectives. According to PMBOK (2013), quality management should include the organizational processes that determine quality policies, objectives and responsibilities. This includes the quality plan, the quality assurance and quality control.

1.8. Problem statement. Refineries process crudes oil into different products such as diesel, jet fuel, LPG, and others. The plant operates 24 hours a day every day, including weekends. Taking the operational conditions into account, it is clear that not all projects can be executed during normal operation of the plant. Therefore, the maintenance shutdowns are opportunities to execute most of the projects. The challenges are centred on completion of those projects safely, on time, within schedule and without compromizing quality. Although turnarounds are planned months in advance, delays and cost escalations are inevitable during the execution phase.

\section{Research methodology}

\subsection{Objectives of the study.}

- To gain understanding of the underlying issues that cause delays, and their root causes.

- To outline the challenges that result in the delays and cost escalations.

- To analyze possible solutions that may remedy the delays and avoid cost escalation issues during shutdowns.

- To make recommendations for corrective or preventative actions to avoid further delays and cost escalations to the benefit of the refinery.

2.2. Construction of the questionnaire. The questionnaire was used as the research instrument. Of the 26 questions asked, 15 were related to the causes of delays in project management during execution and 11 to the causes of cost escalations during project execution.

2.3. Recruitment of study participants. The respondents were the project managers, project engineers, planners, cost controllers and supervisors. The participants were recruited through informal discussions regarding the issues, costs and delays that are experienced during project execution. This was done to make it easy for them to agree to participate in the study without asking too many questions.

2.4. Pre-testing and validation. Three respondents were given hard copies of the questionnaires to answer, to test their comprehension. Confusing questions were rephrased to clarify the meaning and to avoid bias. The pilot study aimed to assess if the instructions were clear and the language and terminology understandable. Furthermore, the pilot study ascertained whether all areas of focus were taken into account, and completion time for the questionnaires could be estimated.

\subsection{Reliability.}

\begin{tabular}{|c|c|}
\hline \multicolumn{2}{|c|}{ Reliability statistics } \\
\hline Cronbach's Alpha & Number of Items \\
\hline 0.624 & 26 \\
\hline
\end{tabular}

The Cronbach's Alpha for the 26 statements was 0.624 . This means that the internal consistency reliability of the measures used in this study is considered to be marginally acceptable.

2.6. Administration of the questionnaires. Questionnaires were personally administered to the respondents in hard copy. Respondents were asked to answer the questionnaires and appointments were 
made to collect the questionnaires within three days. Constant encouragement and follow-ups were done until some questionnaires were completed.

2.7. Limitation of the study. The major limitation of the study is that the results obtained cannot be generalized to different circumstances. The questionnaire design was selected to provide answers to the specific mode of operation of the Engen Refinery turnarounds project execution. These operations could be influenced by various factors like organizational structure, culture, operational philosophies, and operational environment. The other major limitation is that the targeted population is simply the people who are involved in the project execution, like the supervisors, planners, engineers and project managers; however, their experience, training and qualifications were not necessarily taken into consideration. Getting these people to participate in the study was not easy, due to their daily work pressure; they were reluctant to spend their extra time to answer the questions, resulting in a slow respondent rate. The population of 26 participants is small.

2.8. Data handling and analysis. The research data were collected from respondents in hard copies which were scanned and stored in a personal computer (PC). The data were captured using MS Excel and later exported to SPSS which is used to carry out a wide variety of statistical analyzes. Descriptive statistics such as the mean and the median were used to summarize the data. The Kolmogorov-Smirnov Test and One-sample Wilcoxon Signed Rank test were done.

\section{Presentation of results}

In this section, data collected from the questionnaires are presented. All respondents were given the same set of questions to respond to. This was done by ticking or circling the answers they believed were relevant to the question. The responses were recorded in the tables and figures.

3.1. Results. Table 1 shows the overall responses regarding the causes of delays and the cost escalations experienced in project execution during turnarounds. Table 2 records the results of the Kolmogorov-Smirnov test for normality to ascertain the appropriateness of the statistical techniques used to test the hypothesis. Table 3 presents the results of the One-sample Wilcoxon Signed Rank test to assess whether the respondents agreed or disagreed with the statements in the questionnaire.

\subsubsection{Test for normality. The Kolmogorov-Smirnov} test for normality was used to assess if the variables were normally distributed. This was done in order to ascertain the appropriateness of the statistical techniques used to test the hypothesis. If the data are normally distributed, then, parametric tests will be conducted, but if the data are not normally distributed, then, the non-parametric tests will be conducted. The hypotheses for each of these items were as follows:

$\mathrm{H} 0$ : The variable is normally distributed.

$\mathrm{H} 1$ : The variable is not normally distributed.

A variable will be normally distributed if the $p$-values for the Kolmogorov-Smirnov $Z$ are greater than 0.05 , otherwise, they are considered to be not normally distributed. The results are shown in Table 2.

Table 2. Kolmogorov-Smirnov $Z$ test for normality

\begin{tabular}{|c|c|c|c|}
\hline \multicolumn{4}{|c|}{ Tests of normality } \\
\hline & \multicolumn{3}{|c|}{ Kolmogorov-Smirnova } \\
\hline & Statistic & $d f$ & $p$-value \\
\hline Can delays during turnarounds be avoided? & 0.501 & 18 & 0.000 \\
\hline Can poor communication result in a project delay? & 0.523 & 18 & 0.000 \\
\hline Are project scopes clearly defined? & 0.279 & 18 & 0.001 \\
\hline Does any scope change during execution? & 0.421 & 18 & 0.000 \\
\hline Are contracts getting awarded on time? & 0.287 & 18 & 0.000 \\
\hline Are resources get allocated adequately? & 0.225 & 18 & 0.017 \\
\hline Is project execution done by experienced personnel? & 0.294 & 18 & 0.000 \\
\hline Are all stakeholders involved in the planning process? & 0.222 & 18 & 0.019 \\
\hline Is there quality control during project execution? & 0.392 & 18 & 0.000 \\
\hline Are materials procured on time? & 0.253 & 18 & 0.003 \\
\hline Are materials delivered on time? & 0.260 & 18 & 0.002 \\
\hline Any safety incidents during execution? & 0.523 & 18 & 0.000 \\
\hline Are the plants handed over on time to the executing team? & 0.225 & 18 & 0.017 \\
\hline Are the working hours too much during turnaround? & 0.288 & 18 & 0.000 \\
\hline Are there any incentives for job well done? & 0.342 & 18 & 0.000 \\
\hline Can cost escalation during turnarounds be avoided? & 0.463 & 18 & 0.000 \\
\hline Are the project supervisors experienced? & 0.334 & 18 & 0.000 \\
\hline Is communication managed correctly during turnaround? & 0.301 & 18 & 0.000 \\
\hline
\end{tabular}


Table 2 (cont.). Kolmogorov-Smirnov $Z$ test for normality

\begin{tabular}{|l|c|c|c|}
\hline \multicolumn{1}{|c|}{ Tests of normality } \\
\hline \multicolumn{3}{|c|}{ Kolmogorov-Smirnova } \\
\hline Do more people get added to the job during execution, to speed up the job? & 0.346 & 18 & 0.000 \\
\hline Are the budget estimates done correctly? & 0.222 & 18 & 0.019 \\
\hline Is quality control managed by qualified personnel? & 0.245 & 18 & 0.006 \\
\hline Are actions taken for poor quality work? & 0.376 & 18 & 0.000 \\
\hline Is the procurement plan managed by procurement manager? & 0.276 & 18 & 0.001 \\
\hline Is there any scope change during execution? & 0.392 & 18 & 0.000 \\
\hline Is funds allocation adequate? & 0.245 & 18 & 0.006 \\
\hline Do you pay more to expedite if materials not delivered on time? & 0.406 & 18 & 0.000 \\
\hline
\end{tabular}

No $=-1$, Sometimes $=0$ and Yes $=1$.

It is noted that none of the items were normally distributed, since all the p-values were less than 0.05 . The rest of the analysis will be conducted using non-parametric tests, since the variables are not normally distributed.

3.2. Hypothesis testing. The 26 statements were measured on a 3-point scale which was coded as -1 for No, 0 for Sometimes and 1 for Yes. The hypotheses were to assess whether the respondents agreed or disagreed with the statements. The Onesample Wilcoxon Signed Rank test was conducted for each statement against the midpoint of the scale (0). Thus, the hypotheses were as stated below:

H0: The respondents rated sometimes on each statement (median for each statement $t=0$ ).

$\mathrm{H} 1$ : The respondents did not rate sometimes on each statement (median for each statement $t \neq 0$ ).

The results are shown in Table 3.

Table 3a. One-Sample Wilcoxon Signed Rank Test

\begin{tabular}{|c|c|c|c|c|c|}
\hline Null hypothesis & Median & Test & $p$-value & Decision & Mean \\
\hline $\begin{array}{l}\text { The median of Can Poor Communication result in a project } \\
\text { delay? equals } 0\end{array}$ & 1 & $\begin{array}{l}\text { One-Sample Wilcoxon Signed } \\
\text { Rank Test }\end{array}$ & 0.000 & $\begin{array}{l}\text { Reject the null } \\
\text { hypothesis }\end{array}$ & 0.900 \\
\hline $\begin{array}{l}\text { The median of Can delays during turnarounds be avoided? } \\
\text { equals } 0\end{array}$ & 1 & $\begin{array}{l}\text { One-Sample Wilcoxon Signed } \\
\text { Rank Test }\end{array}$ & 0.000 & $\begin{array}{l}\text { Reject the null } \\
\text { hypothesis }\end{array}$ & 0.800 \\
\hline $\begin{array}{l}\text { The median of Any safety incidents during execution? } \\
\text { equals } 0\end{array}$ & 1 & $\begin{array}{l}\text { One-Sample Wilcoxon Signed } \\
\text { Rank Test }\end{array}$ & 0.000 & $\begin{array}{l}\text { Reject the null } \\
\text { hypothesis }\end{array}$ & 0.800 \\
\hline The median of Any scope change during execution? equals 0 & 1 & $\begin{array}{l}\text { One-Sample Wilcoxon Signed } \\
\text { Rank Test }\end{array}$ & 0.000 & $\begin{array}{l}\text { Reject the null } \\
\text { hypothesis }\end{array}$ & 0.650 \\
\hline $\begin{array}{l}\text { The median of Is there quality control during project } \\
\text { execution? equals } 0\end{array}$ & 1 & $\begin{array}{l}\text { One-Sample Wilcoxon Signed } \\
\text { Rank Test }\end{array}$ & 0.000 & $\begin{array}{l}\text { Reject the null } \\
\text { hypothesis }\end{array}$ & 0.650 \\
\hline $\begin{array}{l}\text { The median of Can cost escalation during turnarounds be } \\
\text { avoided? equals } 0\end{array}$ & 1 & $\begin{array}{l}\text { One-Sample Wilcoxon Signed } \\
\text { Rank Test }\end{array}$ & 0.003 & $\begin{array}{l}\text { Reject the null } \\
\text { hypothesis }\end{array}$ & 0.632 \\
\hline $\begin{array}{l}\text { The median of Is there any cost scope change during } \\
\text { execution? equals } 0\end{array}$ & 1 & $\begin{array}{l}\text { One-Sample Wilcoxon Signed } \\
\text { Rank Test }\end{array}$ & 0.001 & $\begin{array}{l}\text { Reject the null } \\
\text { hypothesis }\end{array}$ & 0.600 \\
\hline $\begin{array}{l}\text { The median of If materials not delivered on time do you pay } \\
\text { more to expedite? equals } 0\end{array}$ & 1 & $\begin{array}{l}\text { One-Sample Wilcoxon Signed } \\
\text { Rank Test }\end{array}$ & 0.005 & $\begin{array}{l}\text { Reject the null } \\
\text { hypothesis }\end{array}$ & 0.550 \\
\hline $\begin{array}{l}\text { The median of Do more people get added to the job during } \\
\text { execution, to speed up the job? equals } 0\end{array}$ & 1 & $\begin{array}{l}\text { One-Sample Wilcoxon Signed } \\
\text { Rank Test }\end{array}$ & 0.004 & $\begin{array}{l}\text { Reject the null } \\
\text { hypothesis }\end{array}$ & 0.500 \\
\hline $\begin{array}{l}\text { The median of Are the project supervisors experienced? } \\
\text { equals } 0\end{array}$ & 0 & $\begin{array}{l}\text { One-Sample Wilcoxon Signed } \\
\text { Rank Test }\end{array}$ & 0.003 & $\begin{array}{l}\text { Reject the null } \\
\text { hypothesis }\end{array}$ & 0.450 \\
\hline $\begin{array}{l}\text { The median of Is project execution done by experienced } \\
\text { personnel? equals } 0\end{array}$ & 0 & $\begin{array}{l}\text { One-Sample Wilcoxon Signed } \\
\text { Rank Test }\end{array}$ & 0.011 & $\begin{array}{l}\text { Reject the null } \\
\text { hypothesis }\end{array}$ & 0.400 \\
\hline $\begin{array}{l}\text { The median of Are actions taken for poor quality work? } \\
\text { equals } 0\end{array}$ & 1 & $\begin{array}{l}\text { One-Sample Wilcoxon Signed } \\
\text { Rank Test }\end{array}$ & 0.033 & $\begin{array}{l}\text { Reject the null } \\
\text { hypothesis }\end{array}$ & 0.400 \\
\hline The median of Are project scopes clearly defined? equals 0 & 0 & $\begin{array}{l}\text { One-Sample Wilcoxon Signed } \\
\text { Rank Test }\end{array}$ & 0.035 & $\begin{array}{l}\text { Reject the null } \\
\text { hypothesis }\end{array}$ & 0.350 \\
\hline
\end{tabular}

Table 3b. One-sample Wilcoxon signed rank test

\begin{tabular}{|c|c|c|c|c|c|}
\hline Null hypothesis & Median & Test & $p$-value & Decision & Mean \\
\hline $\begin{array}{l}\text { The median of Is the procurement plan managed by } \\
\text { procurement manager? equals } 0\end{array}$ & 0 & $\begin{array}{l}\text { One-Sample Wilcoxon Signed } \\
\text { Rank Test }\end{array}$ & 0.083 & $\begin{array}{l}\text { Retain the null } \\
\text { hypothesis }\end{array}$ & 0.300 \\
\hline $\begin{array}{l}\text { The median of Are contracts getting awarded on time? } \\
\text { equals } 0\end{array}$ & 0 & $\begin{array}{l}\text { One-Sample Wilcoxon Signed } \\
\text { Rank Test }\end{array}$ & 0.206 & $\begin{array}{l}\text { Retain the null } \\
\text { hypothesis }\end{array}$ & 0.200 \\
\hline The median of Are materials delivered on time? equals 0 & 0 & $\begin{array}{l}\text { One-Sample Wilcoxon Signed } \\
\text { Rank Test }\end{array}$ & 0.206 & $\begin{array}{l}\text { Retain the null } \\
\text { hypothesis }\end{array}$ & 0.200 \\
\hline
\end{tabular}


Table $3 \mathrm{~b}$ (cont.). One-sample Wilcoxon signed rank test

\begin{tabular}{|l|c|l|c|l|l|}
\hline \multicolumn{1}{|c|}{ Null hypothesis } & Median & \multicolumn{1}{|c|}{ Test } & $p$-value & \multicolumn{1}{|c|}{ Decision } & \multicolumn{1}{|c|}{ Mean } \\
\hline $\begin{array}{l}\text { The median of Is communication managed correctly during } \\
\text { turnaround? equals 0 }\end{array}$ & 0 & $\begin{array}{l}\text { One-Sample Wilcoxon Signed } \\
\text { Rank Test }\end{array}$ & 0.157 & $\begin{array}{l}\text { Retain the null } \\
\text { hypothesis }\end{array}$ & 0.200 \\
\hline $\begin{array}{l}\text { The median of Is quality control managed by qualified } \\
\text { personnel? equals 0 }\end{array}$ & 0 & $\begin{array}{l}\text { One-Sample Wilcoxon Signed } \\
\text { Rank Test }\end{array}$ & 0.206 & $\begin{array}{l}\text { Retain the null } \\
\text { hypothesis }\end{array}$ & 0.200 \\
\hline $\begin{array}{l}\text { The median of Are resources getting allocated adequately? } \\
\text { equals 0 }\end{array}$ & 0 & $\begin{array}{l}\text { One-Sample Wilcoxon Signed } \\
\text { Rank Test }\end{array}$ & 0.366 & $\begin{array}{l}\text { Retain the null } \\
\text { hypothesis }\end{array}$ & 0.150 \\
\hline The median of Are materials procured on time? equals 0 & 0 & $\begin{array}{l}\text { One-Sample Wilcoxon Signed } \\
\text { Rank Test }\end{array}$ & 0.527 & $\begin{array}{l}\text { Retain the null } \\
\text { hypothesis }\end{array}$ & 0.100 \\
\hline $\begin{array}{l}\text { The median of Are the plants handed over on time to the } \\
\text { executing team? equals 0 }\end{array}$ & 0 & $\begin{array}{l}\text { One-Sample Wilcoxon Signed } \\
\text { Rank Test }\end{array}$ & 0.763 & $\begin{array}{l}\text { Retain the null } \\
\text { hypothesis }\end{array}$ & 0.050 \\
\hline $\begin{array}{l}\text { The median of Are the working hours too long during } \\
\text { turnaround? equals 0 }\end{array}$ & 0 & $\begin{array}{l}\text { One-Sample Wilcoxon Signed } \\
\text { Rank Test }\end{array}$ & 0.808 & $\begin{array}{l}\text { Retain the null } \\
\text { hypothesis }\end{array}$ & 0.050 \\
\hline $\begin{array}{l}\text { The median of Are all stakeholders involved in the planning } \\
\text { process? equals 0 }\end{array}$ & 0 & $\begin{array}{l}\text { One-Sample Wilcoxon Signed } \\
\text { Rank Test }\end{array}$ & 1.000 & $\begin{array}{l}\text { Retain the null } \\
\text { hypothesis }\end{array}$ & 0.000 \\
\hline $\begin{array}{l}\text { The median of Are the budget estimates done correctly? } \\
\text { equals 0 }\end{array}$ & 0 & $\begin{array}{l}\text { One-Sample Wilcoxon Signed } \\
\text { Rank Test }\end{array}$ & 1.000 & $\begin{array}{l}\text { Retain the null } \\
\text { hypothesis }\end{array}$ & 0.000 \\
\hline The median of Are funds allocation adequate? equals 0 & 0 & $\begin{array}{l}\text { One-Sample Wilcoxon Signed } \\
\text { Rank Test }\end{array}$ & 0.206 & $\begin{array}{l}\text { Retain the null } \\
\text { hypothesis }\end{array}$ & -0.200 \\
\hline $\begin{array}{l}\text { The median of Are there any incentives for job well done? } \\
\text { equals 0 }\end{array}$ & -1 & $\begin{array}{l}\text { One-Sample Wilcoxon Signed } \\
\text { Rank Test }\end{array}$ & 0.071 & $\begin{array}{l}\text { Retain the null } \\
\text { hypothesis }\end{array}$ & -0.368 \\
\hline
\end{tabular}

No $=-1$, Sometimes $=0$ and $\mathrm{Yes}=1$.

The results show that the null hypothesis was rejected for the given statements (Table 3a), since the $p$-values were less than 0.05 and, thus, the median rating was not equal to zero. An assessment of the mean rating shows that the mean ratings for the statements were greater than zero and, thus, the respondents were agreeing with the statements.
The null hypothesis was retained for the rest of the statements listed (Table 3b), since the $p$-values of the One-sample Wilcoxon signed rank test were greater than 0.05 . This means that the respondents could not agree with the statements.

3.3. Graphical results. Below are the graphical results from the participants on the questions asked.

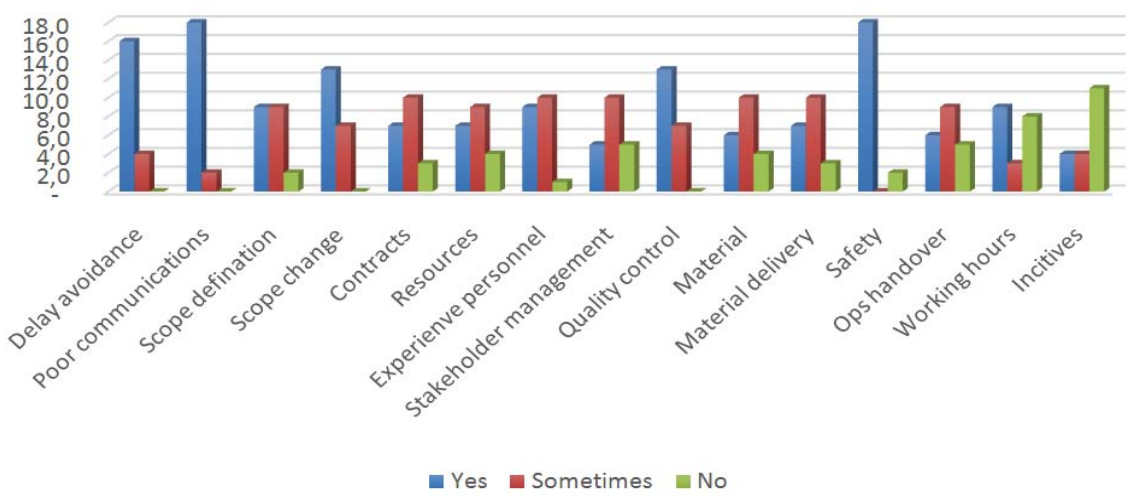

Fig. 1. Delays causes

Figure 1 shows the responses relating to the causes of delays in project execution during turnarounds.

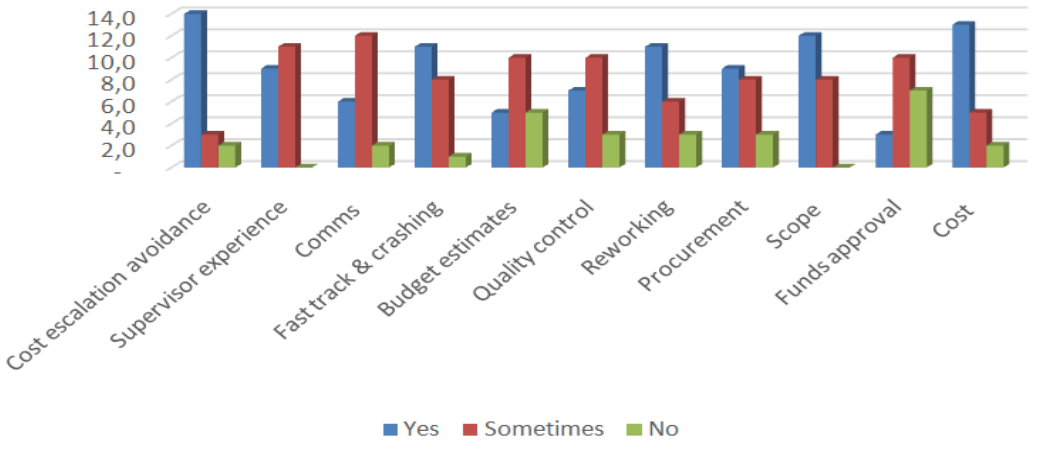

Fig. 2. Cost escalation 
Figure 2 shows the responses relating to the reasons for cost escalation in project execution during turnarounds.

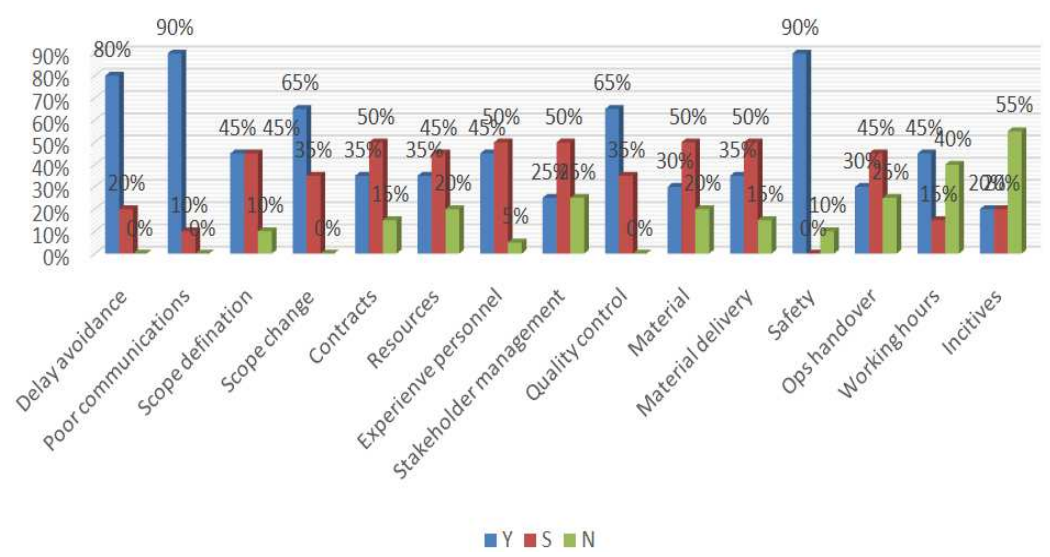

Fig. 3. Delays in \% age

Figure 3 shows the respondents' responses in \% age relating to the causes of delays. $Y=$ Yes, $S=$ sometimes, $N=$ No.

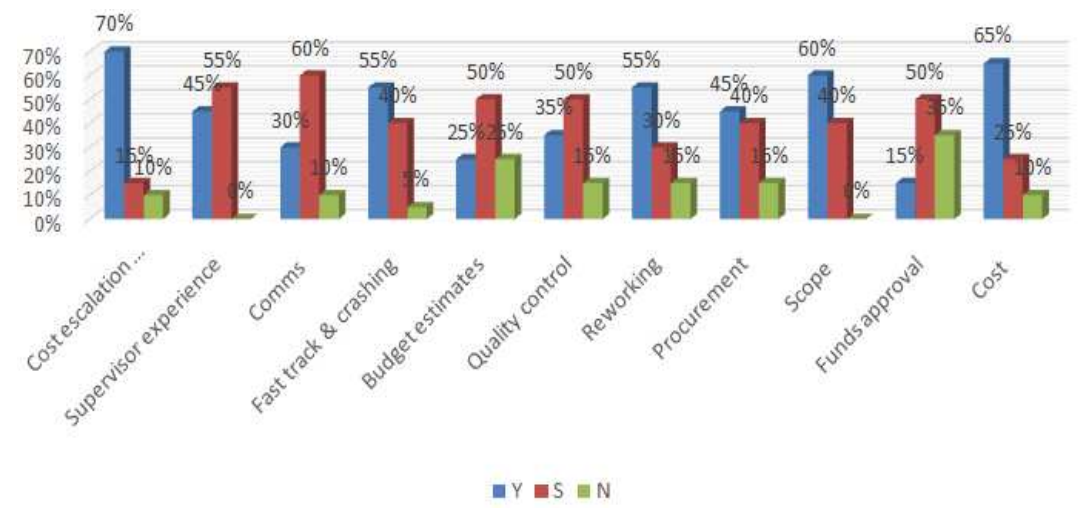

Fig. 4. Cost escalation in $\%$ age

Figure 4 shows the respondents' responses in \% age relating to the cost escalation. $Y=\mathrm{Yes}, S=$ Sometimes, $N=N$.

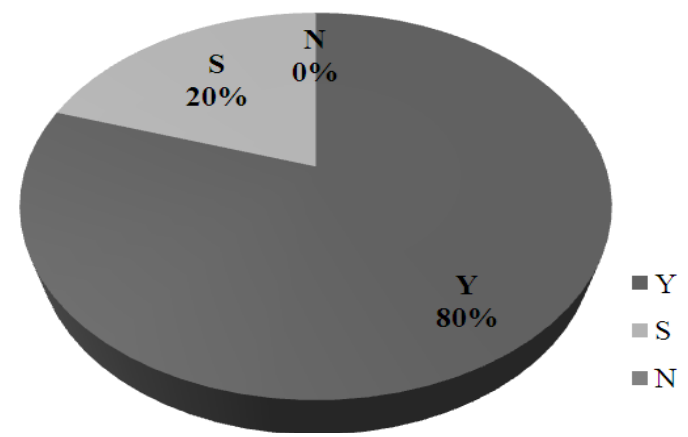

Fig. 5. Delays avoidance

Figure 5 shows the responses relating to respondents who believe that delays in project execution can be avoided during turnarounds. The results indicate that $80 \%$ of the respondents agreed that delays can be avoided and only $20 \%$ are uncertain and no one agreed.

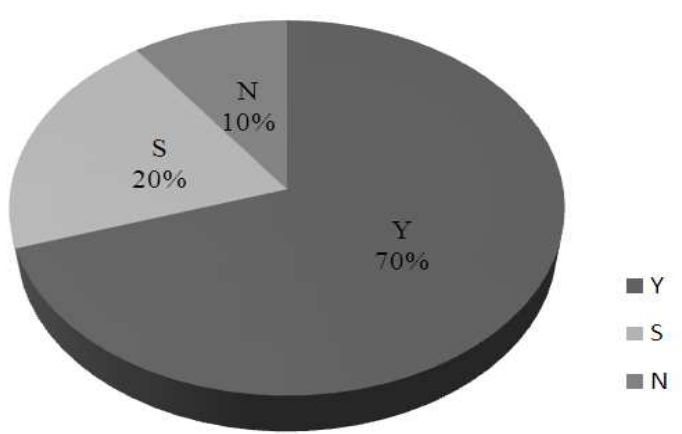

Fig. 6. Cost escalation avoidance

Figure 6 shows the responses relating to respondents who believe that cost escalations in project execution can be avoided during turnarounds. The results indicated that only $70 \%$ of the respondents agreed that cost escalation can be avoided and $10 \%$ disagreed and $20 \%$ are uncertain. 


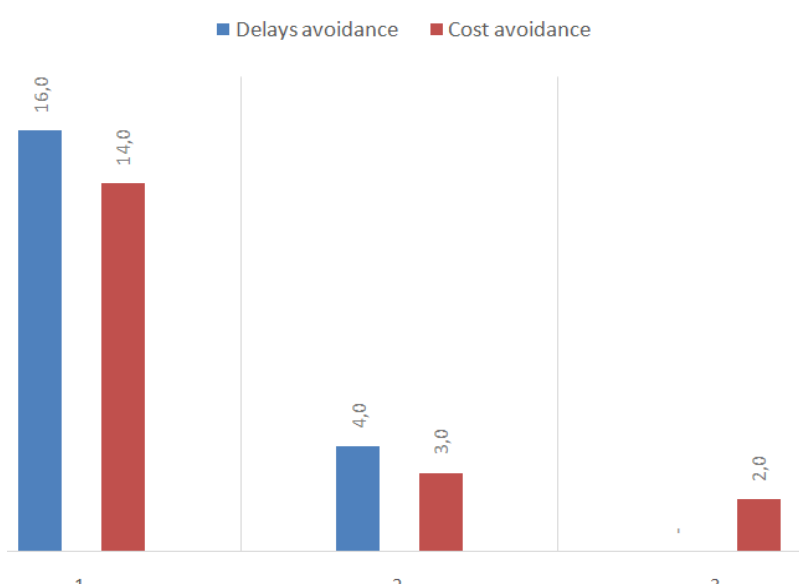

Fig. 7. Delays and cost avoidance

Figure 7 shows responses of respondents on the issues of delays and cost escalations avoidance during the project execution in turnarounds.

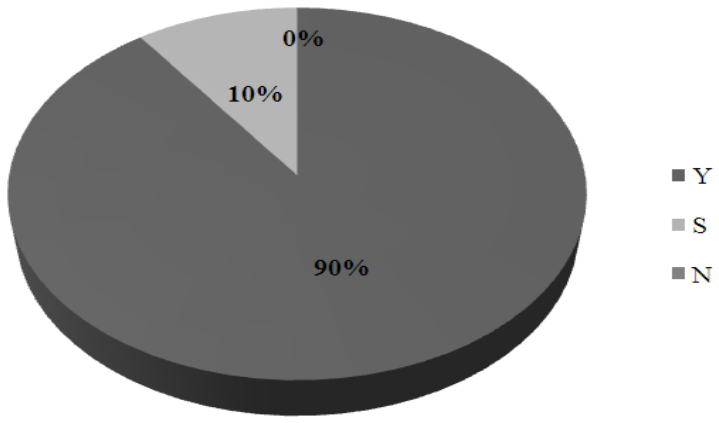

Fig 8. Poor communications results

Figure 8 shows the results of the question on the contribution of poor communication to the causes of delays. The results indicated that $90 \%$ of the respondents agreed that poor communication results in project delays and only $10 \%$ are uncertain.

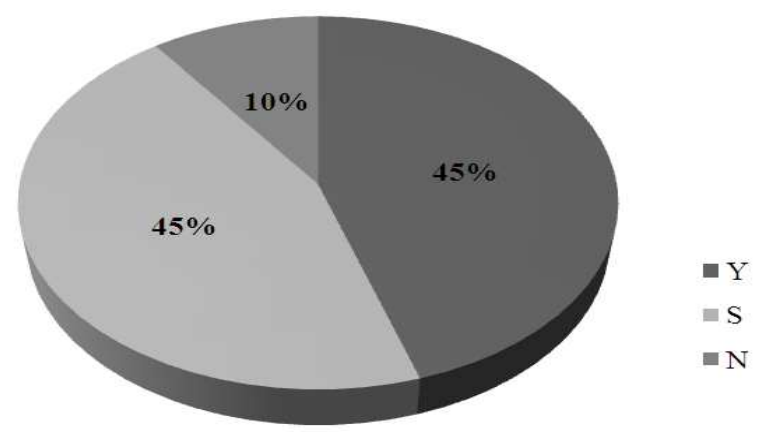

Fig. 9. Scope definition results

Figure 9 shows the results on the question of the contribution of scope definition to the causes of delays in project execution. The results indicated that $45 \%$ of the respondents are agreeing that project scope is clearly defined and $45 \%$ are uncertain, only $10 \%$ are saying scope is not clearly defined.

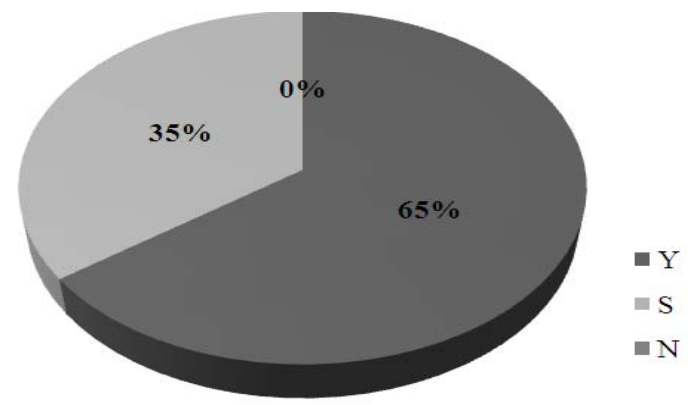

Fig. 10. Scope change results

Figure 10 shows the results on the question of the contribution of scope change to the causes of delays in project execution. The results indicate that $65 \%$ of the respondents are agreeing that there is always a scope change during execution and 35\% saying sometimes it happens.

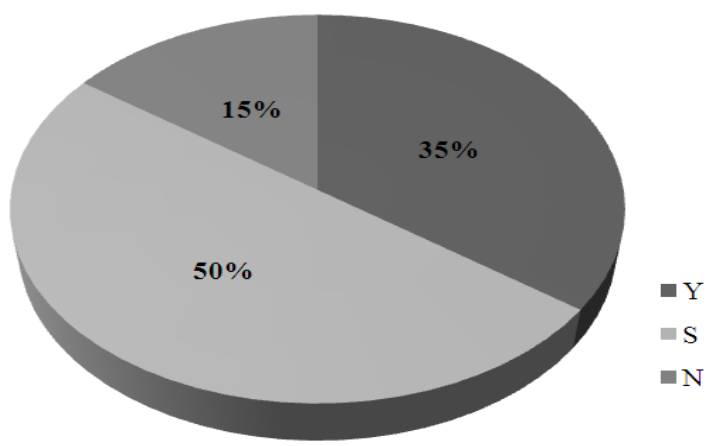

Fig. 11. Contract award

Figure 11 shows the results of the question on the contribution of contract awarding to the causes of delays in project execution. These results indicate that $15 \%$ of the respondents disagree that contracts are awarded on time and $50 \%$ are saying sometimes and only $35 \%$ agrees to the award of contract on time.

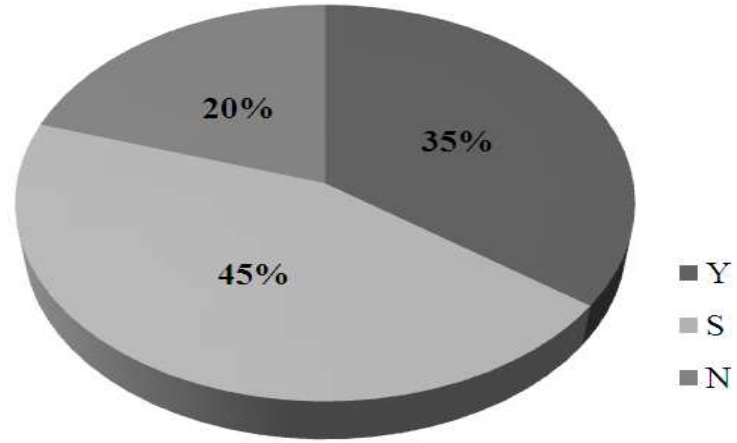

Fig. 12. Resource allocation

Figure 12 shows the results of the question on the contribution of resource allocation to the causes of delays in project execution. The results indicated that $35 \%$ agreed to the adequate resource allocation to the project and $45 \%$ are saying sometimes and only $20 \%$ disagree. 


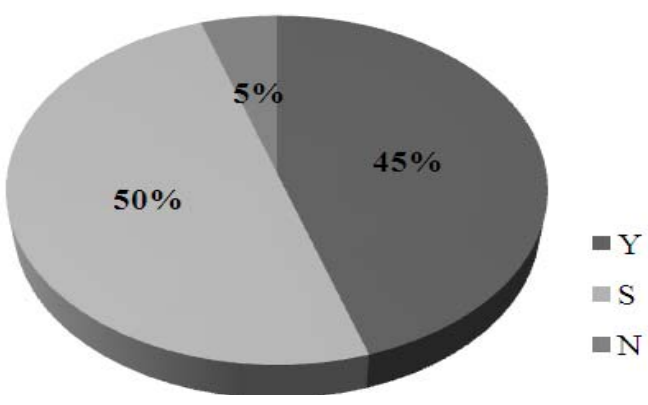

Fig. 13. Experienced personnel

Figure 13 shows the results on the question of experienced personnel involved in the project execution, and their contribution to the causes of delays in project execution. The results showed that only $45 \%$ agreed that work is executed by experienced personnel, $5 \%$ disagreed and $50 \%$ are saying sometimes.

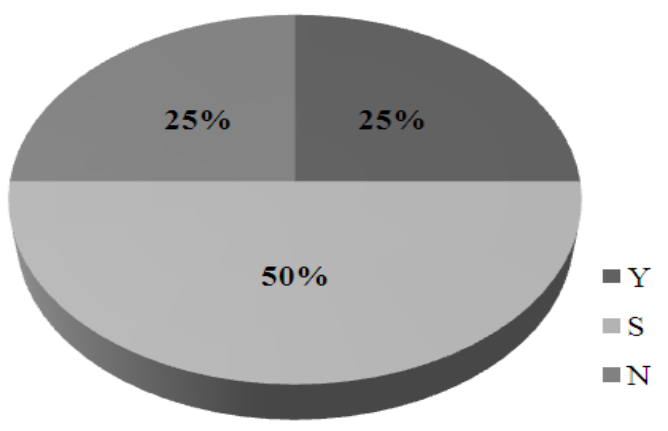

Fig. 14. Stakeholder involvement

Figure 14 shows the results of the question on the contribution of stakeholder involvement to the causes of delays in project execution. The results indicated that $25 \%$ agreed that all stakeholder are involved in the panning process, $25 \%$ disagreed and $50 \%$ are saying sometimes.

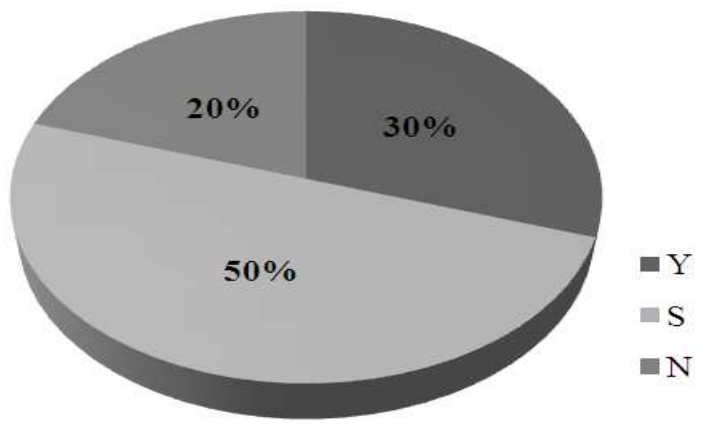

Fig. 15. Material procurement

Figure 15 shows the results of the question on the contribution of procurement of materials to the causes of delays in project execution. The results indicated that $30 \%$ of the respondents agreed that material is procured on time, $50 \%$ says sometimes and only $20 \%$ disagreed.

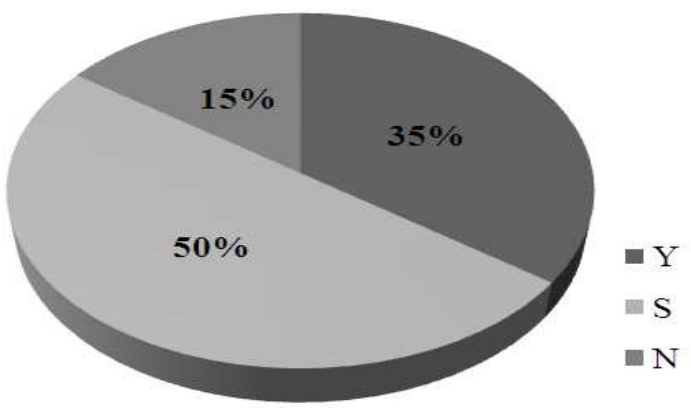

Fig. 16. Material delivery

Figure 16 shows the results of question on the contribution of the delivery of materials to the causes of delays in project execution. The results indicated that $35 \%$ agreed that material is delivered on time, $50 \%$ say sometimes and only $15 \%$ disagreed.

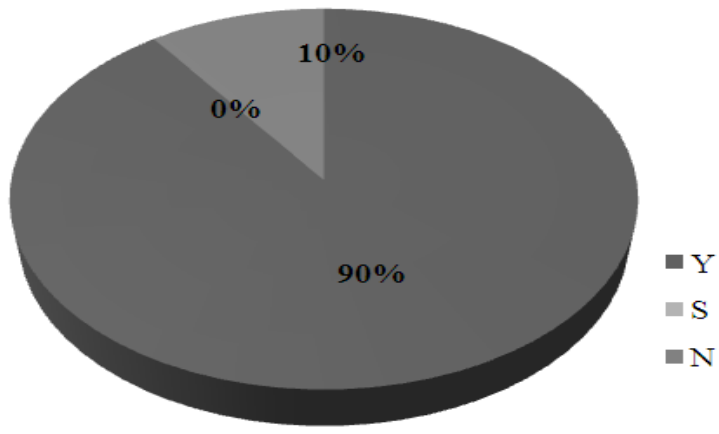

Fig. 17. Safety incidents

Figure 17 shows the results the question on the contribution of safety incidents to the causes of delays in project execution. The results indicated that $90 \%$ agreed that there are safety incidents during project execution and $10 \%$ disagreed.

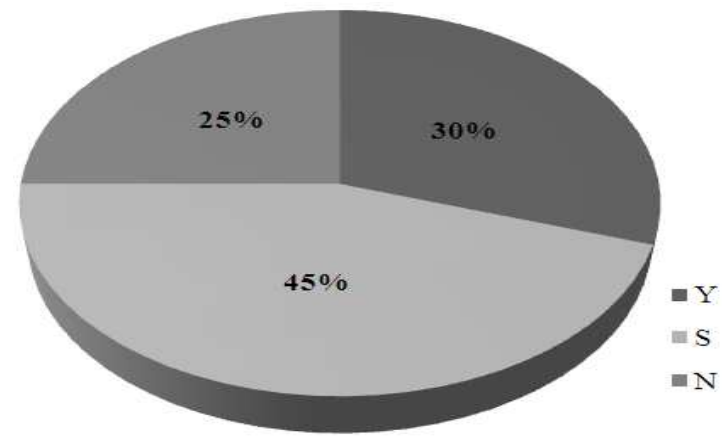

Fig. 18. Plant handover

Figure 18 shows the results the question on the contribution of plant handover to the executing team to the causes of delays in project execution. The results indicated that $30 \%$ agreed that the plant is handed over on time to the executing team, and $25 \%$ disagreed and the $45 \%$ are saying sometimes. 


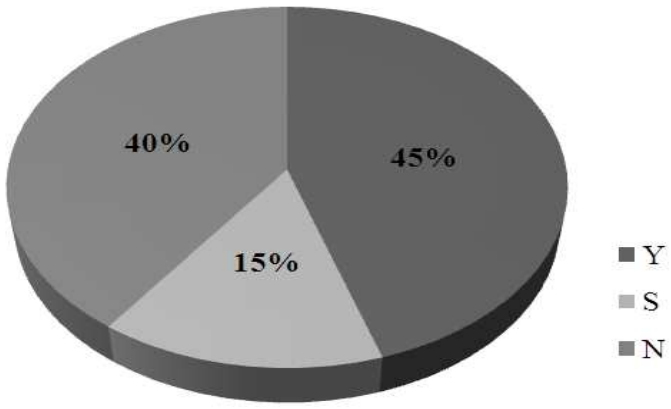

Fig. 19. Working hours

Figure 19 shows the results of the question on the contribution of working hours during execution to the causes of delays in project execution. The results indicated that $45 \%$ agreed that the working hours are too long, $40 \%$ disagreed and $15 \%$ are uncertain.

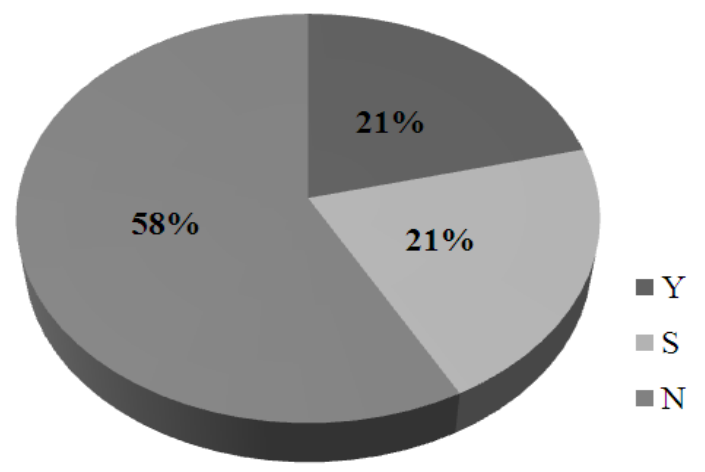

Fig. 20. Incentives for job well done

Figure 20 shows the results of the question on the contribution of incentives for the job well done to the causes of delays in project execution. The results indicated that $21 \%$ agreed that there are incentives for a job well done, another $21 \%$ are saying that happens sometimes and $58 \%$ disagreed.

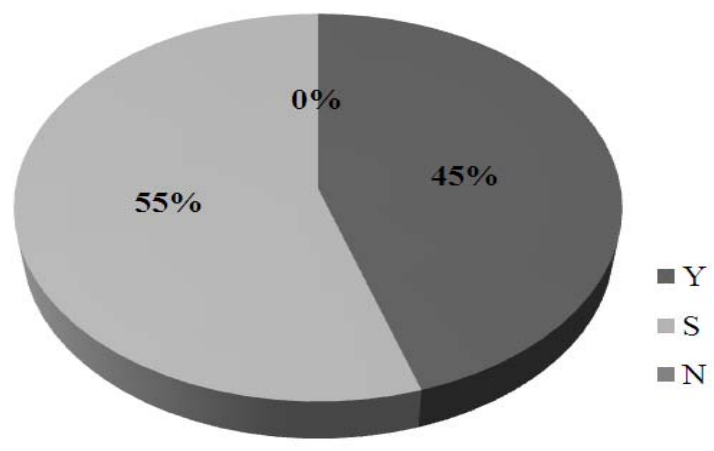

Fig. 21. Experienced supervision

Figure 21 shows the results of the question on the contribution of experienced supervision available or involved to the causes of cost escalation in project execution. The results indicated that $45 \%$ agreed that project supervisors are experienced, and 55\% says that happened sometimes.

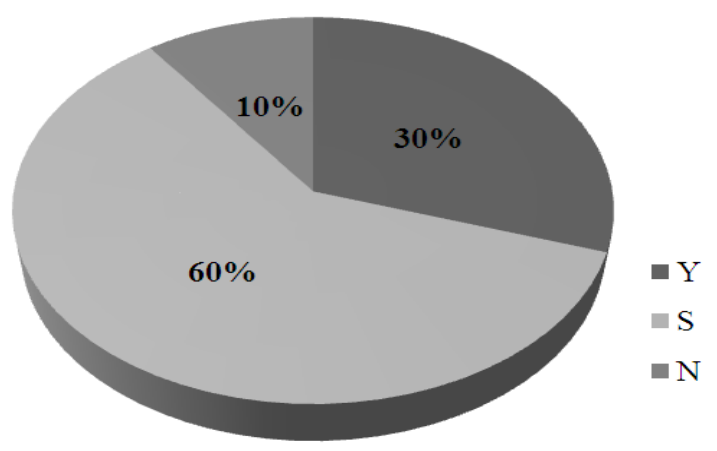

Fig. 22. Communication management

Figure 22 shows the results of the question on the contribution of communication management to the causes of delays and cost escalation in project execution. The results indicated that only 30\% agreed that communication is managed correctly, $60 \%$ says sometimes and $10 \%$ disagree.

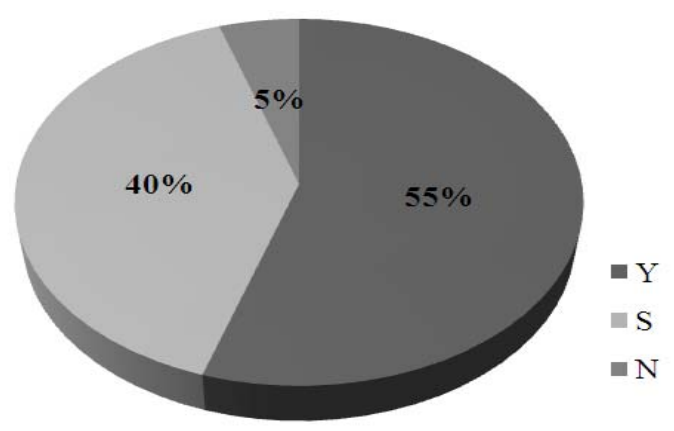

Fig. 23. Personnel addition

Figure 23 a shows the results the question on the contribution of adding personnel to meet deadlines to the causes of cost escalation in project execution. The results indicated that $55 \%$ agreed to project crashing and $40 \%$ said sometimes and only $5 \%$ disagree.

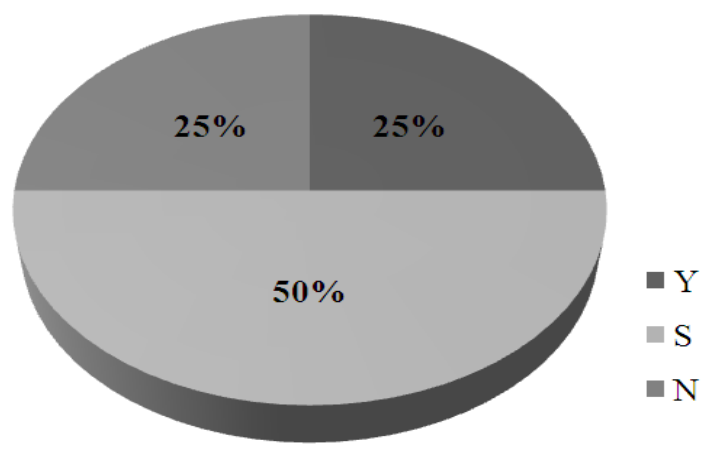

Fig. 24. Budget estimates

Figure 24 shows the results the question on the contribution of budget estimates to the causes of cost escalation in project execution. The results indicated that $25 \%$ agreed that budget estimates are done correctly, $25 \%$ disagreed and $50 \%$ said sometimes. 


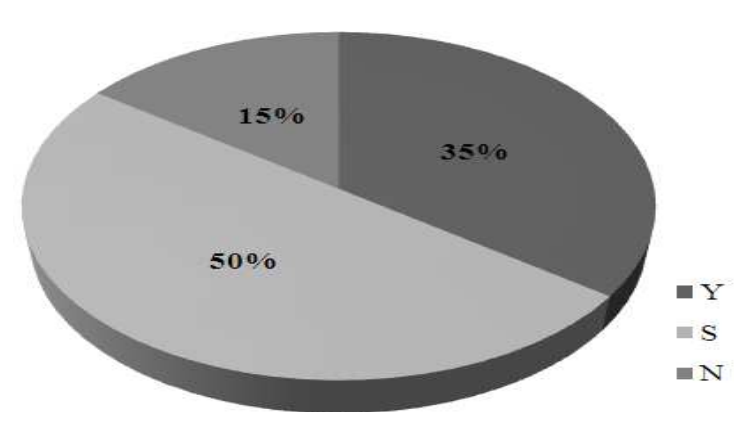

Fig. 25. Quality control management

Figure 25 shows the results of the question on the contribution of quality control management to the causes of cost escalation in project execution. The results indicated that $35 \%$ agreed that quality control is managed by qualified quality controllers, $15 \%$ disagree and $50 \%$ said sometimes.

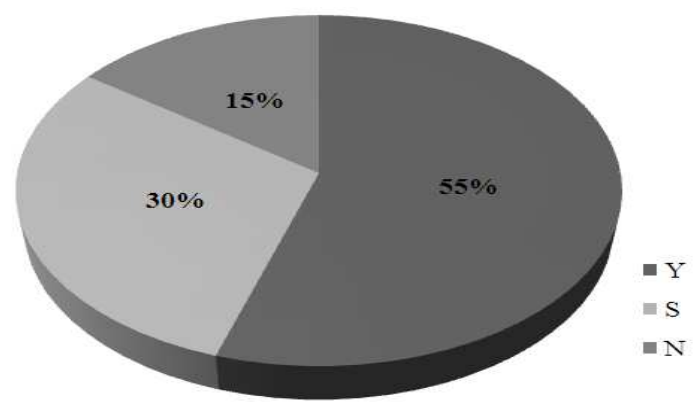

Fig. 26. Poor quality corrections

Figure 26 shows the results of the question on the contribution of poor quality corrections to the causes of cost escalation in project execution. The results indicated that 55\% agreed that actions are taken to prevent poor quality from occurring again, $30 \%$ said sometimes and $15 \%$ disagreed.

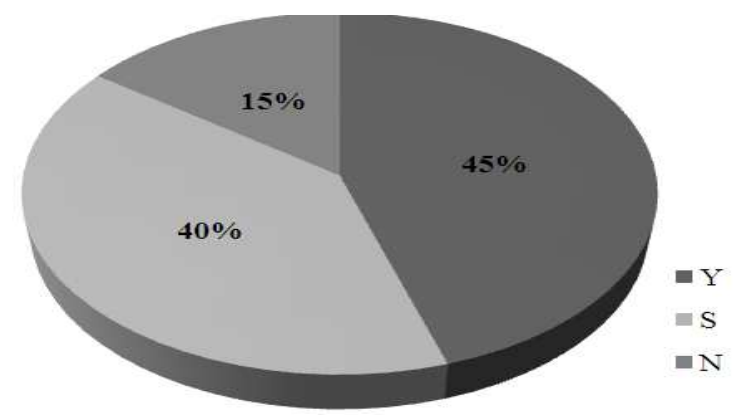

Fig. 27. Procurement management

Figure 27 shows the results of the question on the contribution of procurement management to the causes of cost escalation in project execution. The results showed that $45 \%$ agreed that procurement is managed by a procurement manager, $40 \%$ said sometimes and $15 \%$ disagreed.

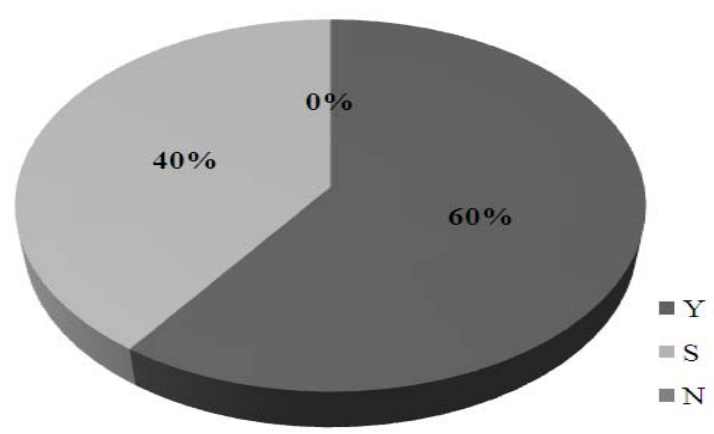

Fig. 28. Scope change cost

Figure 28 shows the results of the question on the contribution of scope change to the causes of cost escalation in project execution. These results indicated that $60 \%$ of the respondents agreed that scope change results in cost escalation, and only $40 \%$ are saying sometimes and no one disagrees.

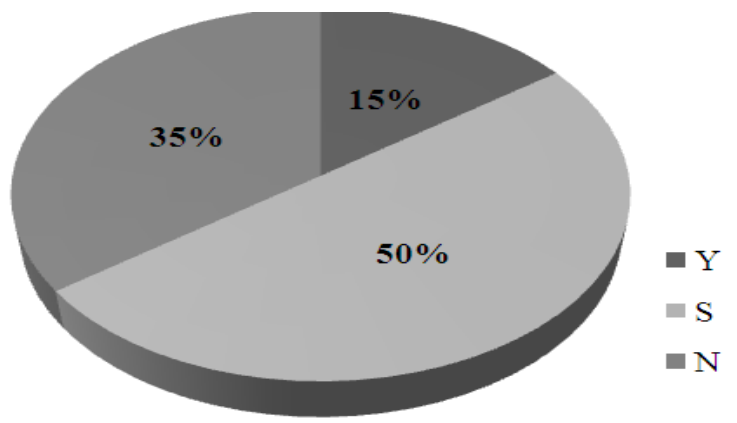

Fig. 29. Funds allocation

Figure 29 shows the results of the question on the contribution of funds allocation $\mathrm{c}$ to the causes of cost escalation in project execution. The results showed that $15 \%$ agreed that funds allocation to projects is adequate, $50 \%$ said sometimes and $35 \%$ disagreed.

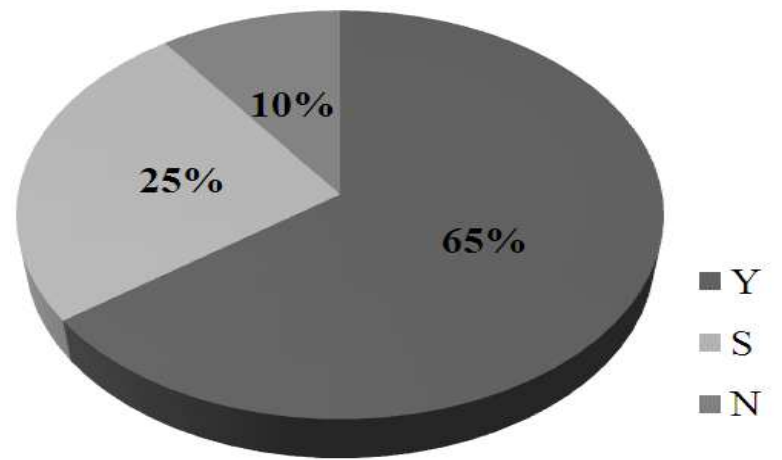

Fig. 30. Acceleration cost

Figure 30 shows the results of the question on the contribution of acceleration payments to the causes of cost escalation in project execution. The results indicated that $65 \%$ of the respondents agreed that more is paid to expedite material delivery, $25 \%$ said sometimes and $10 \%$ disagreed. 


\section{Conclusions and recommendations}

In this section, we present the findings, conclusions and recommendations.

\section{Conclusions}

Findings from the study indicate that poor communication is a major contributor to delays and cost escalations in project execution during turnarounds at Engen Refinery. Safety incidents during turnarounds further lead to delays and, consequently, cost escalation. If a safety incident happens, the job should be stopped completely while an investigation is under way, until the main cause is established and corrective actions are put in place to avoid another incident. The lesson learnt from the incident should be shared with the whole organization.

Although the scope is clearly defined, scope change does happen during execution and contributes to delays. Changes in scope inevitably result in review of the schedule, cost and plans, which takes time to adjust. Cost escalation can be avoided during project execution. Materials are not procured on time, which affects delivery time and, consequently, more is paid to expedite delivery.

There are always quality issues resulting from unqualified quality control inspectors, however, actions are taken to avoid repetition. There are experienced people executing projects during the shutdown.

The cost related to acceleration of materials delivery, communication, scope change and quality are major contributors to cost escalation, followed by inexperienced supervision and poor budget estimates.

\section{Recommendations}

Delays. It is very encouraging to see that most respondents believe that delays in project execution can be avoided. It is recommended that poor communication should be avoided, as it has been found a major contributor to the causes of delays. Communications should be administered at all levels about the objectives of the projects to be executed.

Although scope definition does not seem to be a major problem, the scope definition should be improved to avoid any gaps which lead to scope change and result in conflicts. The research found that scope is changed mostly during execution and, therefore, it is recommended that the scope should be fixed before execution. Scope should be defined by specialists in the field to avoid missing some important elements. This should minimize the need for scope changes during execution. Any foreseen changes should be budgeted for and have resources allocated to and this should be part of the recovery plan.
It is recommended that contracts be placed on time as far as possible and any activities delaying contracts placement identified and attended to as early as possible. This will allow contractors to prepare thoroughly. It is also recommended that the allocation of adequate resources should be improved.

The literature indicates that stakeholders are those people that affect or could be affected by the project. One of the research findings is that not all of them are involved at the beginning of the project. It is, therefore, recommended to involve all stakeholders at the beginning of the project. The quality control should also be improved. The purchasing of long lead materials should be improved, and, consequently, the delivery of those materials should also improve.

Research findings further indicate that safety incidents occur most of the time during project execution. Focus should be directed to avoid the safety incidents, as they cost money and reduce allocated resources. The plant handover for execution has been found as another obstacle that delays the starting time. This is a tricky issue, as plant would not be handed over for execution unless it is made safe. Proper planning, however, could improve the situation.

The working hours are believed to be adequate, however, people should be encouraged to rest during the rest days, which is difficult to manage. Most respondents said that there are no incentives for jobs well done. It is recommended that incentives be introduced for jobs well done to encourage work excellence and quality. However, transparent criteria should be agreed upon in advance to avoid conflict and discouragement of teams that think they deserve the incentives, when they are not and not incentivizing those who deserve.

Costs. It is very encouraging that most respondents felt that cost escalations can be avoided during project execution in turnarounds at Engen Refinery. It is, therefore, recommended that communication should be improved during turnarounds so that every individual is up to date with all developments.

Resource planning should be improved to avoid adding resources in the middle of the project execution, as those resources come at a cost that is not budgeted for. The budget estimates should be improved as well, since research findings indicate that budgeting is not done correctly. Budget estimate software should be purchased and used by the organization in order to avoid cost escalation resulting from incorrect budgets. 
Quality controls should be improved during project execution. The procurement processes should be improved. The scope change during project execution should be avoided at all cost. The scope should be fixed before execution commences, and any scope change should be approved and monitored closely by the project managers, supervisors and engineers.

The allocation of funds is linked to the budget estimates. If estimates are not done correctly, chances are that fund allocation will be inadequate. Adequate allocation of funds will avoid going back to the investment committee to ask for additional funding during execution as that is regarded as cost escalation.
It is further recommended that a study should be carried out in the future to establish methods that could be used to improve the gaps identified in the elements that contribute to these delays and cost escalations.

Further studies. The current study was carried out at Engen Refinery and the focus was directed to delays and cost escalation in executing projects during turnarounds. Delays and cost escalations also affects projects that are executed outside turnarounds. It is, therefore, recommended that future studies should focus on delays in project execution with Engen refinery as a whole. The findings can be integrated into the Project Management System of the organization.

\section{References}

1. Albrecht, J.C. and Spang, K. (2014). Linking the benefits of project management maturity to project complexity, International Journal of Managing Projects in Business, 7(2), pp. 285-301.

2. Andersen, B., Samset K., Welde M. (2016). How estimates - high stakes: underestimation of costs at the front-end of projects, International Journal of Managing Projects in Business, 9(1), pp.171-193.

3. Assaf, S.A. and Al-Hejji, S. (2006). Causes of delay in large construction projects, International Journal of Project Management, 24(4), pp. 349-357.

4. Budd, C.S. and Budd, C.I. (2003). Earned value. Project Management Institute.

5. Burke, R. (2013). Project management, planning and control techniques (5 ed.). New York: Wiley.

6. Cameron, L. (2014). Maitenance execution and shutdowns best practice. Retrieved September 20, 2014. Available at: https://www.google.co.za/\#q=maintenance+execution+\%26+shutdowns+best+practice.

7. Doloi, H. (2013). Cost overruns and failure in project management: understanding the roles of key stakeholders in construction projects, Journal of Construction Engineering and Management, 193(3), pp. 267-279.

8. Drouin, N. and Jugdev, K. (2014). Standing on the shoulders of strategic management giants to advance organizational project management, International Journal of Managing Projects in Business, 7(1), pp. 61-77.

9. Dursun, O. and Stoy, C. (2016). Conceptual Estimation of Construction Costs Using the Multistep Ahead Approach, Journal of Construction Engineering and Management, pp. 1943-7862.

10. Ertl, B. (2014). Applying PMBOK to shutdowns, turnaround and outages. Retrieved September 20, 2014, from: http://www.maintenanceonline.co.uk/maintenanceonline/content_images/918.pdf

11. Hagen, M. and Park, S. (2013). Ambiguity acceptance as a function of project management: a new critical success factor, Project Management Journal, 44(2), pp. 52-66.

12. Hjelmbrekke, H. and Lohne, O.L. (2014). The need for a project governance body, International Journal of Managing Projects in Business, 7(4), pp. 661-677.

13. Larson, R. and Larson, E. (2009). Top five causes of scope creep: and what to do about them. Project Management Institute.

14. Muller, R. and Judgev, K. (2012). Critical success factors in projects, International Journal of Managing Projects in Business, 5(4), pp. 757-775.

15. Lahdenperä, P. (2016). Preparing a framework for two-stage target-cost arrangement formulation, International Journal of Managing Projects in Business, 9(1), pp. 123-146.

16. Lavingia, N.J. (2003). Improve profitability through effective project management and total cost management, Cost Engineering, 45(11), pp.

17. Patrick, D. and Warchalowski, J. (2013). Gaining competitive advantage through reducing project lead times, Project Management Institute.

18. Pmbok, T. (2013). Guide to the project management body of knowledge (5 ed.). Pennysylvania: Project Management Institute.

19. Render, B., Stair, R.M., Hanna, M.E. and Hale, T.S. (2015). Quantitative analysis for management (12 ed.). Essex, England: Pearson Education.

20. Rolstadas, A., Tommelein, I., Schiefloe, P.M. and Ballard, G. (2014). Understanding project success through analysis of project management approach, International Journal of Managing Projects in Business, 7(4), pp. 638-660.

21. Savelsbergh, C.M.J.H., Havermans, L.A., Storm, P. (2016). Development paths of project managers: what and how do project managers learn from their experiences? International Journal of Project Management, 34(4), pp. 559-569.

22. Sondalini, M. (2009). Shutdowns and Turnarounds 2009 Conference. Retrieved September 21, 2014, from: www.lifetime-reliability.com. 


\section{Appendix}

Table 1. Respondent results

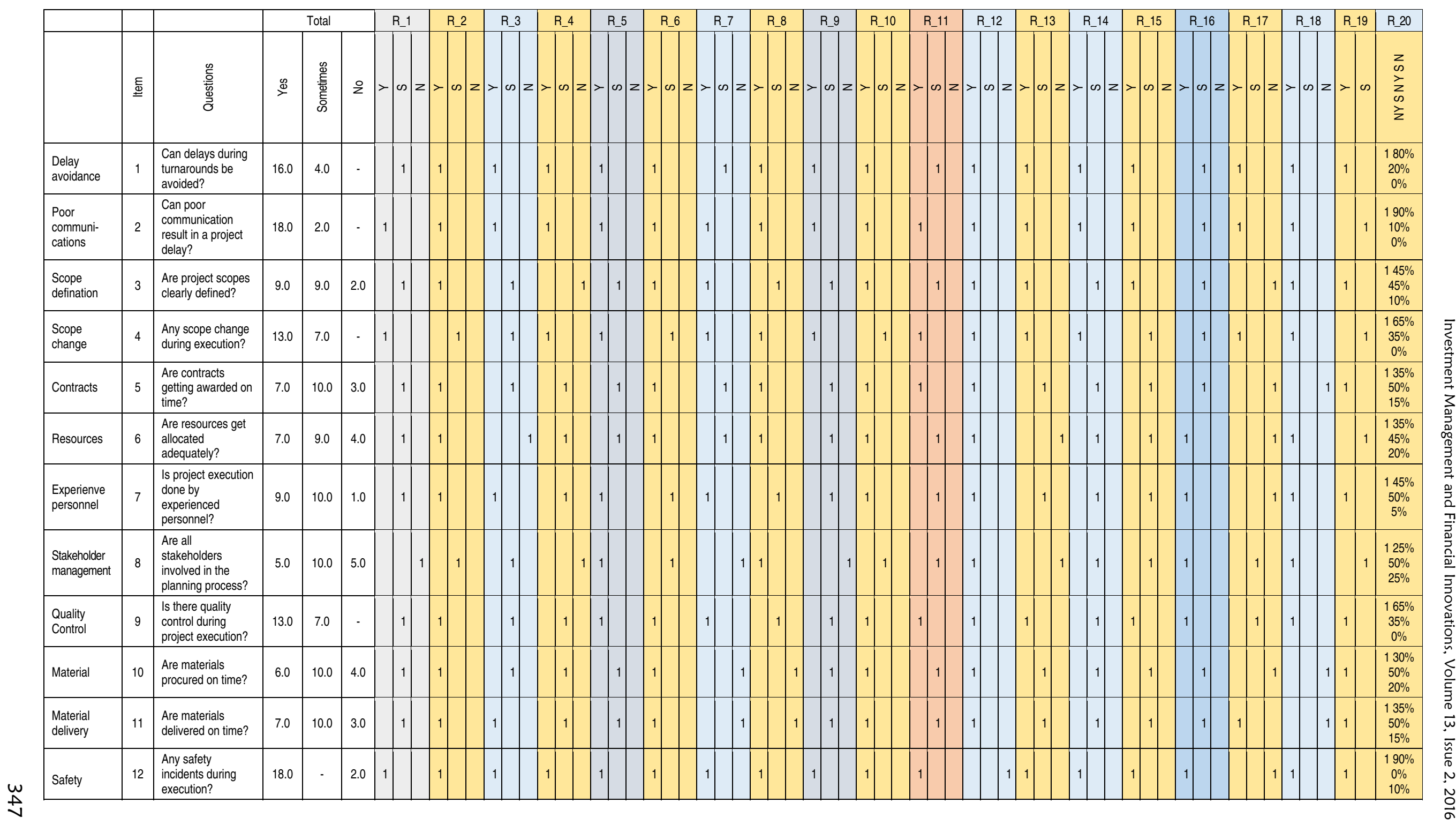




\begin{tabular}{|c|c|c|c|c|c|c|c|c|c|c|c|c|c|c|c|c|c|c|c|c|c|c|c|c|c|c|c|c|c|c|c|c|c|c|c|c|c|c|c|}
\hline $\begin{array}{l}\text { Ops } \\
\text { handover }\end{array}$ & 13 & \begin{tabular}{|l} 
Are the plants \\
handed over on \\
time to the \\
executing team?
\end{tabular} & 6,0 & 9,0 & 5,0 & & 1 & & 1 & 1 & & 1 & & 1 & 1 & & & \begin{tabular}{|l|l|}
1 & 1 \\
\end{tabular} & & & 1 & & 1 & 1 & 1 & & 1 & & 1 & 1 & & 1 & & & 1 & & 1 & 1 & $\begin{array}{c}130 \% \\
45 \% \\
25 \% \\
\end{array}$ \\
\hline $\begin{array}{l}\text { Working } \\
\text { hours }\end{array}$ & 14 & \begin{tabular}{|l} 
Are the working \\
hours too much \\
during turnaround?
\end{tabular} & 9,0 & 3,0 & 8,0 & & & 1 & & 1 & & & 1 & 1 & 1 & & & 1 & & \begin{tabular}{l|l|l}
1 & 1 &
\end{tabular} & & 1 & & 1 & & 1 & & 1 & & $1 \quad 1$ & & & 1 & 1 & & 1 & & 1 & $\begin{array}{l}145 \% \\
15 \% \\
40 \% \\
\end{array}$ \\
\hline Incitives & 15 & \begin{tabular}{|l} 
Are there any \\
incentives for job \\
well done?
\end{tabular} & 4,0 & 4,0 & $\begin{array}{c}11, \\
0\end{array}$ & & 1 & & & 1 & & & 1 & 1 & 1 & & 1 & & 1 & 1 & 1 & 1 & & & \begin{tabular}{l|l}
1 & 1
\end{tabular} & & & 1 & 1 & & 1 & 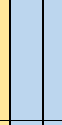 & & 1 & & 1 & & & $\begin{array}{l}11 \\
20 \% \\
20 \% \\
55 \% \\
\end{array}$ \\
\hline $\begin{array}{l}\text { Cost } \\
\text { escalation } \\
\text { avoidance }\end{array}$ & 16 & \begin{tabular}{|l|} 
Can cost escalation \\
during turnarounds \\
be avoided?
\end{tabular} & 14,0 & 3,0 & 2,0 & 1 & & & 1 & & 1 & & 1 & & 1 & & & \begin{tabular}{|l|l|}
1 & 1 \\
\end{tabular} & & 1 & & 1 & & & 1 & & 1 & & 1 & 1 & & . & 1 & 1 & & 1 & 1 & & $\begin{array}{l}170 \% \\
15 \% \\
10 \%\end{array}$ \\
\hline $\begin{array}{l}\text { Supervisor } \\
\text { experience }\end{array}$ & 17 & \begin{tabular}{|l|}
$\begin{array}{l}\text { Are the project } \\
\text { supervisisors } \\
\text { experienced? }\end{array}$ \\
\end{tabular} & 9,0 & 11,0 & - & & 1 & 1 & & 1 & & 1 & 1 & & 1 & & 1 & & 1 & & 1 & 1 & & 1 & 1 & & 1 & & 1 & 1 & & . & 1 & 1 & & 1 & 1 & & $\begin{array}{l}145 \% \\
55 \% \\
0 \%\end{array}$ \\
\hline Comms & 18 & \begin{tabular}{|l|} 
Is communication \\
managed correctly \\
during turnaround? \\
\end{tabular} & 6,0 & 12,0 & 2,0 & & 1 & 1 & & 1 & & & \begin{tabular}{l|l|l|}
1 & 1
\end{tabular} & & 1 & & & 1 & 1 & & 1 & 1 & & 1 & 1 & & 1 & & 1 & & 1 & 1 & & 1 & & 1 & & 1 & $\begin{array}{l}130 \% \\
60 \% \\
10 \%\end{array}$ \\
\hline $\begin{array}{l}\text { Fast track \& } \\
\text { crashing }\end{array}$ & 19 & \begin{tabular}{|l|} 
Do more people \\
get addded to the \\
job during \\
execution, to speed \\
up the job?
\end{tabular} & 11,0 & 8,0 & 1,0 & & 1 & 1 & & 1 & & 1 & 1 & & 1 & & 1 & 1 & & & 1 & 1 & & 1 & 1 & & 1 & & & 1 & 1 & 1 & & 1 & & 1 & & 1 & $\begin{array}{c}155 \% \\
40 \% \\
5 \%\end{array}$ \\
\hline $\begin{array}{l}\text { Budget } \\
\text { estimates }\end{array}$ & 20 & \begin{tabular}{|l}
$\begin{array}{l}\text { Are the budget } \\
\text { estimates done } \\
\text { correctly? }\end{array}$ \\
cors
\end{tabular} & 5,0 & 10,0 & 5,0 & & 1 & 1 & & 1 & & & \begin{tabular}{ll|l}
1 & 1
\end{tabular} & & 1 & & 1 & & 1 & & & 1 & & 1 & 1 & & 1 & 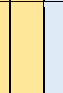 & 1 & & 1 & & & & 1 & & \begin{tabular}{|l|l|}
1 & 1 \\
\end{tabular} & & $\begin{array}{l}125 \% \\
50 \% \\
25 \%\end{array}$ \\
\hline $\begin{array}{l}\text { Quality } \\
\text { control }\end{array}$ & 21 & \begin{tabular}{|l|} 
Is quality control \\
managed by \\
qualified \\
personnel?
\end{tabular} & 7,0 & 10,0 & 3,0 & & 1 & 1 & 1 & 1 & & & 1 & 1 & 1 & & & 1 & 1 & & 1 & 1 & & 1 & 1 & & & 1 & & 1 & & 1 & & 1 & & 1 & & 1 & $\begin{array}{l}135 \% \\
50 \% \\
15 \%\end{array}$ \\
\hline Reworking & 22 & \begin{tabular}{|l}
$\begin{array}{l}\text { Are actions taken } \\
\text { for poor quality } \\
\text { work? }\end{array}$ \\
\end{tabular} & 11,0 & 6,0 & 3,0 & & & & 1 & & & 1 & 1 & & 1 & & 1 & & 1 & 1 & & 1 & & & \begin{tabular}{l|l}
1 & 1
\end{tabular} & & 1 & & & 1 & 1 & 1 & & 1 & & 1 & 1 & & $\begin{array}{l}155 \% \\
30 \% \\
15 \%\end{array}$ \\
\hline Procurement & 23 & \begin{tabular}{|l|} 
Is the procurement \\
plan managed by \\
procurement \\
manager?
\end{tabular} & 9,0 & 8,0 & 3,0 & & 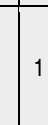 & 1 & & & \begin{tabular}{l|l}
1 & 1
\end{tabular} & & 1 & & 1 & & 1 & 1 & & & & 1 & & 1 & 1 & & 1 & & 1 & & 1 & . & 1 & 1 & & 1 & & 1 & $\begin{array}{l}145 \% \\
40 \% \\
15 \%\end{array}$ \\
\hline Scope & 24 & \begin{tabular}{|l|} 
Is there any scope \\
change during \\
execution?
\end{tabular} & 12,0 & 8,0 & - & 1 & & 1 & 1 & 1 & 1 & & 1 & & 1 & & 1 & 1 & & 1 & & 1 & & 1 & & 1 & 1 & & 1 & 1 & & 1 & & 1 & & 1 & & 1 & $\begin{array}{l}160 \% \\
40 \% \\
0 \%\end{array}$ \\
\hline $\begin{array}{l}\text { Funds } \\
\text { approval }\end{array}$ & 25 & \begin{tabular}{|l|} 
Are funds \\
allocation \\
adequate?
\end{tabular} & 3,0 & 10,0 & 7,0 & & 1 & 1 & 1 & 1 & & & 1 & 1 & 1 & & 1 & & 1 & 1 & & 1 & & 1 & & 1 & 1 & & 1 & & 1 & 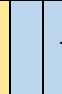 & 1 & & 1 & & 1 & 1 & $\begin{array}{l}115 \% \\
50 \% \\
35 \%\end{array}$ \\
\hline Cost & 26 & \begin{tabular}{|l|} 
If materials not \\
delivered on time \\
do you pay more to \\
expedite?
\end{tabular} & 13,0 & 5,0 & 2,0 & & & & 1 & 1 & 1 & & 1 & & 1 & & 1 & 1 & & 1 & & 1 & & 1 & & 1 & 1 & & 1 & 1 & & . & 1 & 1 & & 1 & 1 & 1 & $\begin{array}{l}165 \% \\
25 \% \\
10 \%\end{array}$ \\
\hline
\end{tabular}

